\title{
Survival of Bifidobacterium longum LMG 13197 microencapsulated in Vegetal or Vegetal-inulin matrix in simulated gastrointestinal fluids and yoghurt
}

\author{
Andreal Chioma Amakiri ${ }^{1}$ and Mapitsi Silvester Thantsha $12^{1 *}$
}

*Correspondence: mapitsi.

thantsha@up.ac.za

${ }^{2}$ Department

of Microbiology and Plant

Pathology, Faculty of Natural

and Agricultural Sciences,

University of Pretoria,

New Agricultural Sciences

Building, Lunnon Road,

Pretoria 0002, South Africa

Full list of author information

is available at the end of the

article

\begin{abstract}
Background: Vegetal BM 297 ATO is a food grade lipid based material extracted from vegetables, and certified for human consumption. In this study, Bifidobacterium longum LMG 13197 was encapsulated in Vegetal BM 297 ATO-inulin by freeze drying, followed by evaluation of its survival in simulated gastrointestinal fluids and yoghurt. Furthermore, the effect of incorporation of such microparticles on physico-chemical properties of yoghurt was examined. Unencapsulated and encapsulated B. longum cells were exposed to simulated gastrointestinal fluids for $6 \mathrm{~h}$ and yoghurt at $4{ }^{\circ} \mathrm{C}$ for 6 weeks, and then evaluated for viability using plate counts.
\end{abstract}

Results: By the end of exposure to simulated gastrointestinal fluids, encapsulated cells were $>5 \mathrm{log}$ units higher than their unencapsulated counterparts. Furthermore, their levels in yoghurt remained above $10^{6} \mathrm{cfu} \mathrm{mL}^{-1}$ until the end of 6 weeks of storage while unencapsulated levels were at this level up to 5 weeks. There were no significant differences in $\mathrm{pH}$ values of yoghurts containing encapsulated cells throughout the storage ( $p>0.05$ ). However, significant differences in the lightness and yellowness of these yoghurts were recorded, although the total colour change was negligible.

Conclusions: Vegetal-inulin encapsulation protected probiotics in gastrointestinal fluids and yoghurt with negligible effects to its appearance, thus can be used for fortification of yoghurt with probiotics.

Keywords: Lipid excipients, Microencapsulation, Probiotics, Vegetal, Inulin, Simulated gastrointestinal fluids

\section{Background}

Probiotics have been described as "live microorganisms which when administered in adequate amounts confer a health benefit on the host" (FAO/WHO 2002). Over the years, consumers have become aware of the benefits of ingesting fermented foods which contain probiotics. Yogurt is one of the oldest fermented milk products and the most common dairy products consumed around the world (Shah 2000). The purpose for its production and consumption is to improve health and reduce the occurrence of gastrointestinal diseases (Roberfroid 2007). The increasing popularity of yogurt has led food industries and various researchers to continuously investigate how best to add value to

c) 2016 The Author(s). This article is distributed under the terms of the Creative Commons Attribution 4.0 International License (http://creativecommons.org/licenses/by/4.0/), which permits unrestricted use, distribution, and reproduction in any medium, provided you give appropriate credit to the original author(s) and the source, provide a link to the Creative Commons license, and indicate if changes were made. 
yoghurt products to attract health-conscious consumers (Allgeyer et al. 2010). More recently, yoghurt has been fortified with live microorganisms called probiotics, mainly lactobacilli and bifidobacteria. However, viability of probiotics and the universal quality of many probiotic-containing products is still a major issue, as the number of viable probiotics and especially bifidobacteria decline over time in dairy foods during storage and subsequently during gastrointestinal transit (Sultana et al. 2000). Poor survival and viability of bifidobacteria in yoghurt results in counts lower than $10^{6}-10^{7} \mathrm{cfu} \mathrm{g}^{-1}$, which is the recommended daily intake needed to confer health benefits (Doleyres and Lacroix 2005). Probiotic survival in fermented products is affected by a range of factors including $\mathrm{pH}$, dissolved oxygen, storage temperature and post-acidification (Shah 2000).

In order to protect probiotic cultures during processing, storage in food products and during gastrointestinal transit, innovative technologies such as microencapsulation, as well as the addition of prebiotics have been explored (Fritzen-Freire et al. 2012). Studies have shown that microencapsulation improves probiotic survival during transit in the human gastrointestinal transit, during manufacturing and storage in yoghurt (Kailasapathy 2006; Thantsha et al. 2009). Prebiotics have received increasing attention because of their beneficial health effects as well as their ability to improve food quality (Capela et al. 2006). In food technology, prebiotics such as inulin have been used to improve texture and mouthfeel, as stabilizers, fat replacers, and flavour enhancers in food products such as yoghurt (Pimentel et al. 2013). Inulin has also been used as ingredients in functional foods as well as dietary supplements, because they are regarded safe for consumption (Kelly 2009).Products containing both probiotic and prebiotic components are generically termed synbiotics (Kalliomäki 2009). These products affords the food industries with a strategy to both provide physical barriers to protect the probiotics from detrimental conditions, as well as give suitable nutrients that will selectively enhance proliferation of the probiotics (Doleyres and Lacroix 2005; Thantsha et al. 2009).

During the process of microencapsulation, coating materials such as starch, gellan gum, alginate and k-carrageenan have been mostly utilized (Burgain et al. 2011). However, the use of food grade lipid coating materials for preparation of synbiotic products suitable for incorporation into foods is yet to be fully investigated. Vegetal BM 297 ATO is a glyceryl distearate produced from vegetables with melting temperatures between 53 and $58{ }^{\circ} \mathrm{C}$. Vegetal can be used as a dietary supplement and thus is certified safe for human consumption (Gattefossé SAS, technical and material data sheets 2010). The aim of this study was to assess the effect of encapsulation with Vegetal BM 297 ATO in conjunction with inulin on the survival of Bifidobacterium longum LMG 13197in simulated gastrointestinal fluids, yoghurt and the resultant effect of the microparticles on the physico-chemical properties of yoghurt.

\section{Methods}

\section{Reagents and bacterial cultures}

Biogapress Vegetal BM 297 ATO was obtained in powdered form from Gattefossé SAS (France). B. longum LMG 13197 cultures were obtained in freeze-dried form from BCCM/LMG Culture collection (Belgium), revived according to the manufacturer's specifications and then kept as $20 \%$ glycerol stocks in de Man, Rogosa, Sharpe (MRS) broth (Sigma Aldrich, South Africa) at $-70{ }^{\circ} \mathrm{C}$. Inulin (purity: $95 \%$ ), polyvinyl alcohol 
(PVA) 87-89 \% partially hydrolysed (Mw: 13,000-23,000 Da), lactose monohydrate (purity: $99 \%$ ) were obtained from Sigma Aldrich, South Africa, while dichloromethane (DCM) (analytical grade, purity: 99 \%) was obtained from Sigma Aldrich Laborchemikalien, Seelze.

\section{Encapsulation of bacteria}

One millilitre of overnight B. longum LMG 13197 culture was subcultured into three $250 \mathrm{~mL}$ flasks containing $100 \mathrm{~mL}$ MRS-cys- $\mathrm{HCl}$ broth, and incubated overnight in a shaking incubator $(250 \mathrm{rpm})$ at $37{ }^{\circ} \mathrm{C}$. Cells were then harvested by centrifugation, using an Eppendorf centrifuge 5804R (at $4{ }^{\circ} \mathrm{C}$ ) at $20,800 \times g$ for $15 \mathrm{~min}$. The pelleted cells (approximately $3.14 \times 10^{8} \mathrm{cfu} \mathrm{mL}^{-1}$ ) were washed once with Ringer's solution and kept at $4{ }^{\circ} \mathrm{C}$ for 5 min before encapsulation. The first emulsion was prepared by suspending the bacterial pellet into $1 \mathrm{~mL}$ of $(2 \% \mathrm{w} / \mathrm{v})$ inulin. The bacteria-inulin mixture was then added to $1 \mathrm{~mL}$ of $(2 \% \mathrm{w} / \mathrm{v})$ poly-vinyl-alcohol (PVA). The resulting suspension was subsequently added to $10 \mathrm{~mL}$ of dichloromethane (DCM) containing (10\% w/v) Vegetal BM 297 ATO. This emulsion was homogenized at $8000 \mathrm{rpm}$ for $5 \mathrm{~min}$ using a Silverson, L4R, NIMR homogenizer and left to stand at $25{ }^{\circ} \mathrm{C}$. The second emulsion was prepared by mixing $15 \mathrm{~mL}$ of $(2 \% \mathrm{w} / \mathrm{v})$ PVA and $5 \mathrm{~mL}$ of $(5 \% \mathrm{w} / \mathrm{v})$ lactose. The first emulsion was mixed into the second emulsion and homogenised at $8000 \mathrm{rpm}$ for $5 \mathrm{~min}$ using a Silverson, L4R, NIMR homogenizer (Stewart and Brierley Pty Ltd., South Africa). The stable emulsion was left to stand in the fume hood for $5 \mathrm{~h}$ for DCM evaporation. After evaporation of DCM, the sample was frozen at $-20{ }^{\circ} \mathrm{C}$ overnight. This was followed by freeze drying using a Virtis bench top, SLC, freeze dryer for 3 days at $-75^{\circ} \mathrm{C}$. The freeze dryer was set at a condenser temperature and vacuum pressure of $-60{ }^{\circ} \mathrm{C}$ and 0.26 millitor, respectively.

The same protocol was used to prepare Vegetal BM 297 ATO microparticles encapsulating B. longum LMG 13197 without inulin, except bacterial pellet was re-suspended in $1 \mathrm{~mL}$ of deionised water before mixing with $1 \mathrm{~mL}$ of $(2 \% \mathrm{w} / \mathrm{v})$ PVA. The unencapsulated cells was prepared by re-suspending B. longum cells (approximately $3.14 \times 10^{8}$ cfu $\mathrm{mL}^{-1}$ ) into $25 \mathrm{~mL}$ of sterile $1 / 4$ strength Ringer's solution and fast-frozen in liquid nitrogen. The fast-frozen cells were then frozen at $-70{ }^{\circ} \mathrm{C}$ for $1 \mathrm{~h}$, and then freeze dried as was done for encapsulated cells. All the freeze dried samples were stored in tightly sealed sterile Schott bottles at $4{ }^{\circ} \mathrm{C}$ for further analysis within $10 \mathrm{~h}$.

\section{Survival of bacteria in simulated gastrointestinal fluids (SGIF)}

Simulated gastric fluid (SGF) was prepared according to Lian et al. (2003). Briefly, pepsin (P7000, 1:10,000, ICN, Sigma Aldrich, South Africa) $\left(3 \mathrm{~g} \mathrm{~L}^{-1}\right)$ was suspended in sterile $\mathrm{NaCl}$ solution $(0.5 \% \mathrm{w} / \mathrm{v})$. The $\mathrm{pH}$ of the solution was adjusted to $\mathrm{pH} 2.0$ with $12 \mathrm{M} \mathrm{HCl}$, and then filter sterilized through a $0.22 \mu \mathrm{m}$ filter membrane (Pall Corporation, USA). Simulated intestinal fluid (SIF) was prepared according to US Pharmacopoeial (2005). Briefly, $6.8 \mathrm{~g}$ of monobasic potassium phosphate (Sigma, St. Louis, MO, USA) was dissolved in $250 \mathrm{~mL}$ of distilled water, followed by addition of $77 \mathrm{~mL}$ of $0.2 \mathrm{M} \mathrm{NaOH}$ and $500 \mathrm{~mL}$ of distilled water. The solution was vortexed for $30 \mathrm{~min}$ and then $10 \mathrm{~g}$ of pancreatin (P-1500, Sigma, St. Louis, MO, USA) was added and mixed. The solution was adjusted to $\mathrm{pH} 6.8$ with $0.2 \mathrm{M} \mathrm{NaOH}$ or $0.2 \mathrm{M} \mathrm{HCl}$. The total volume of the solution was 
made up to $1000 \mathrm{~mL}$, followed by filtration through a $0.45 \mu \mathrm{m}$ filter membrane to remove particulate material, and then filter sterilized through a $0.22 \mu \mathrm{m}$ filter membrane.

One gram of unencapsulated and encapsulated samples was then dispersed into separate test tubes containing $9 \mathrm{~mL}$ of SGF (pH 2.0). The tubes were vortexed for $30 \mathrm{~s}$ and incubated at $37^{\circ} \mathrm{C}$ in a shaker incubator (Lasec, LM-575R) at $50 \mathrm{rpm}$ for $2 \mathrm{~h}$. One millilitre subsamples were withdrawn from the tubes at 30 min intervals for $2 \mathrm{~h}$ after vortexing of tubes containing the unencapsulated cells and gentle pipetting of the encapsulated samples. Bacteria in the subsamples were then enumerated using plate count assay (PCA). Bacteria remaining in SGF after withdrawal of the $2 \mathrm{~h}$ subsample were pelleted by centrifugation using a LabnetPrism ${ }^{\text {TM }}$ Microcentrifuge at $7,267 \times g$ for $5 \mathrm{~min}$. The pellets were resuspended in $9 \mathrm{~mL}$ of SIF ( $\mathrm{pH}$ 6.8) and incubated as before. One millilitre subsamples were taken at $2 \mathrm{~h}$ intervals until $6 \mathrm{~h}$ for bacterial enumeration. After removal of each subsample, sterile SGF or SIF equal to the subsample withdrawn was added to the tube to maintain the concentration of sample.

\section{Survival of encapsulated $B$. longum LMG 13197 in yoghurt}

Two hundred and fifty millilitres of skimmed milk was supplemented with $3 \% \mathrm{w} / \mathrm{v}$ of non fat dry powdered milk in three flasks. The milk mix was homogenised by thoroughly swirling the flasks and then pasteurised at $72{ }^{\circ} \mathrm{C}$ for $30 \mathrm{~min}$. It was then cooled to $42{ }^{\circ} \mathrm{C}$, inoculated $\left(6 \% \mathrm{w} / \mathrm{v}\right.$, ca $\left.1 \times 10^{6} \mathrm{cfu} \mathrm{mL}^{-1}\right)$ with lactic culture containing Streptococcus thermophilus and Lactobacillus delbrueckii subsp bulgaricus and incubated at $45^{\circ} \mathrm{C}$ until a pH of 4.53 was attained. Yoghurt was pasteurized at $72{ }^{\circ} \mathrm{C}$ for $30 \mathrm{~min}$ to kill the starter cultures as previously done by Sun and Griffiths (2000), before addition of bifidobacteria. One millilitre of yoghurt samples were pour plated onto M-17 and MRS-cys-HCl agar plates to confirm absence of viable S. thermophilus and L. bulgaricus, respectively, prior to addition of bifidobacteria. Then $30 \mathrm{~mL}$ of the fermented yoghurt was poured into $50 \mathrm{~mL}$ sterile containers and aseptically mixed with $1 \mathrm{~g}$ of either unencapsulated or encapsulated cells and stored at $4{ }^{\circ} \mathrm{C}$ for 6 weeks. Viability of Bifidobacterium cells in stored yoghurt was determined weekly using PCA. The ' 0 day' analysis was carried out after overnight cold storage of samples.

\section{Physico-chemical analysis of yoghurt}

The $\mathrm{pH}$ and colour of stored yoghurts were measured weekly in triplicates. The $\mathrm{pH}$ was measured using a Crison Basic $20 \mathrm{pH}$ meter (Denver instruments, USA). The colour was analysed using a Minolta Chroma Meter CR-400 (Konica Minolta, Osaka, Japan) calorimeter. The total colour difference $\left(\Delta \mathrm{E}^{*}\right)$ between the unencapsulated and encapsulated samples was calculated as previously done by Fritzen-Freire et al. (2012) using the equation:

$$
\Delta \mathrm{E}^{*}=\left[\left(\Delta \mathrm{L}^{*}\right)^{2}+\left(\Delta \mathrm{a}^{*}\right)^{2}+\left(\Delta \mathrm{b}^{*}\right)^{2}\right]^{1 / 2}
$$

where $\mathrm{L}^{*}$ represents variations from black to white, $\mathrm{a}^{*}$ represents variations from red + to green - and $b^{*}$ represents variations from yellow + to blue - . 


\section{Enumeration of $B$. longum cells}

The subsamples withdrawn from SGF, SIF and yoghurt were serially diluted in $1 / 4$ strength Ringer's solution. The samples withdrawn from yoghurt were first resuspended into $9 \mathrm{~mL}$ of DCM and vortexed for $30 \mathrm{~s}$ to disrupt the lipid matrix and release the bacteria before performing a serial dilution. Then aliquots of $100 \mu \mathrm{L}$ of each dilution were pour-plated in triplicates onto MRS agar plates supplemented with $0.05 \% \mathrm{cys}-\mathrm{HCl}$. The plates were incubated at $37{ }^{\circ} \mathrm{C}$ for $72 \mathrm{~h}$ in anaerobic jars with Anaerocult A gaspaks and Anaerocult $\mathrm{C}$ test strips to indicate anaerobic conditions in the jar.

\section{Statistical analysis}

A completely randomized design was used in this study and data was analysed using a one way analysis of variance (ANOVA). Mean values and standard deviations were calculated from the data obtained from three independent trials, the difference between the means was calculated using Least Significant Difference (LSD) and a p-value less than 0.05 was considered to be statistically significant. Analysis was performed using Statistica version 6.0 (StatsoftInc, Tulsa, USA).

\section{Results}

Survival of $B$. longum LMG 13197 in simulated gastrointestinal fluids

A reduction of $2.34 \log _{10} \mathrm{cfu} \mathrm{mL}^{-1}$ in viable counts of unencapsulated bacteria was recorded after their exposure to SGF (Fig. 1). Vegetal encapsulated bacteria showed an initial decrease of viable counts from 7.16 to $6.95 \log _{10} \mathrm{cfu} \mathrm{mL}^{-1}$ after the first $30 \mathrm{~min}$ of exposure to SGF (Fig. 1). This was followed by an increase in the number of cells to $7.30 \log _{10} \mathrm{cfu} \mathrm{mL}^{-1}$ after $2 \mathrm{~h}$. Similarly, Vegetal-inulin encapsulated bacteria showed a decrease from an initial count of 5.93 to $5.87 \log _{10}$ cfu mL ${ }^{-1}$ within the first $30 \mathrm{~min}$ of exposure to SGF, followed by an increase in cells to $6.43 \log _{10} \mathrm{cfu} \mathrm{mL} \mathrm{L}^{-1}$ after $2 \mathrm{~h}$ (Fig. 1). The numbers of cells released from Vegetal and Vegetal-inulin matrix at the end of exposure to SGF were 0.90 and $0.60 \log _{10}$ cfu $\mathrm{mL}^{-1}$, respectively.

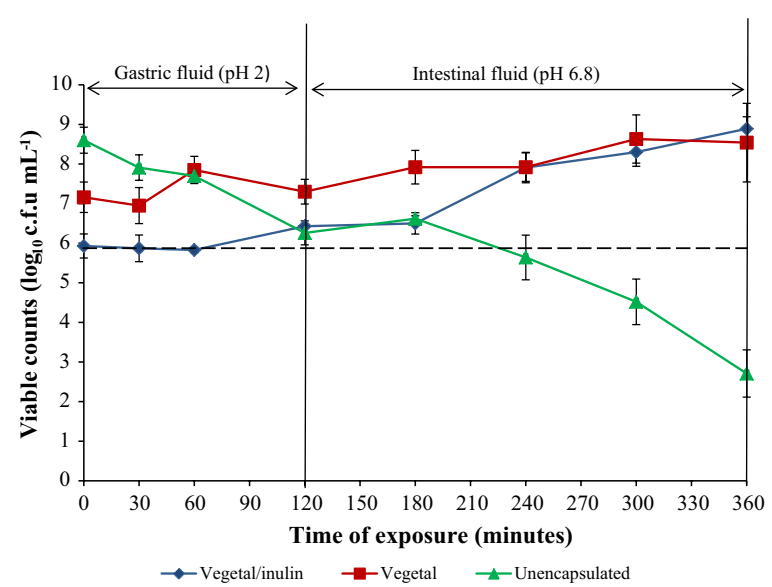

Fig. 1 Survival of unencapsulated and encapsulated B. longum LMG 13197 after exposure to simulated gastrointestinal fluids over $6 \mathrm{~h}$. Each point represents the average of triplicate counts from three independent trials and error bars are standard deviations of three replicates. The dotted line represents the minimum recommended viability level for probiotics 
Upon subsequent exposure to SIF, the numbers of the unencapsulated bacteria continued to decrease, with total bacterial cell loss of $5.89 \log$ units after $6 \mathrm{~h}$ (Fig. 1). The numbers of viable cells released immediately following exposure in SIF were 0.62 and 0.07 log units for Vegetal and Vegetal-inulin matrixes, respectively. Both Vegetal and Vegetalinulin matrixes showed continuous release of cells above $10^{6} \log _{10} \mathrm{cfu} \mathrm{mL} \mathrm{mL}^{-1}$ in SIF, with no significant difference $(p>0.05)$ at the end of $6 \mathrm{~h}$. The numbers of Vegetal and Vegetalinulin encapsulated bacteria in SIF showed increases of 1.24 and 2.46 log units, respectively at the end of exposure.

\section{Survival of $B$. longum LMG 13197 in yoghurt and its effects on the $\mathrm{pH}$ and colour of yoghurt} during storage

Unencapsulated cells showed $2.70 \mathrm{log}$ unit reduction in viability during storage in yoghurt whereas encapsulated cells showed increases of 0.9 and $1.9 \log$ units for Vegetal and Vegetal-inulin encapsulated cells, respectively (Fig. 2). Viable counts for bacteria encapsulated by both matrices were lower than those of unencapsulated bacteria after overnight storage, and were also less than their counts recorded after 6 weeks of storage in yoghurt. However, their levels in both occasions were above $6 \log \mathrm{cfu}$, the minimum recommended level of viability for probiotics to confer the beneficial effects in consumers. Interestingly, levels of these cells were higher after 6 weeks than those of unencapsulated cells, whose levels decreased below the minimum recommended value. At the end of storage, viable numbers of bacteria encapsulated by both matrices were significantly higher $(\mathrm{p}<0.05)$ than levels of unencapsulated cells. Furthermore, viability was significantly higher $(\mathrm{p}<0.05)$ for Vegetal-inulin encapsulated bacteria than those encapsulated in Vegetal alone.

The $\mathrm{pH}$ of yoghurt containing unencapsulated bacteria decreased by 0.21 , with significant differences $(\mathrm{p}<0.05)$ observed from the fourth to sixth week of storage (Table 1$)$. Conversely, the $\mathrm{pH}$ of yoghurts containing Vegetal and Vegetal-inulin encapsulated bacteria decreased by 0.05 and 0.06 units, respectively by the sixth week. The reduction of

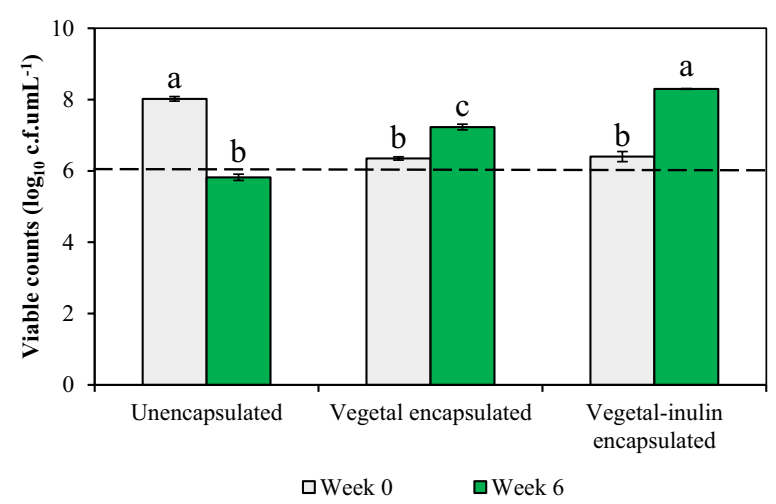

Fig. 2 Survival of unencapsulated and encapsulated B. longum LMG 13197 in yoghurt at $4{ }^{\circ} \mathrm{C}$ for 6 weeks. Each bar represents the average of triplicate counts from three independent trials and error bars are standard deviations of three replicates. The dotted line represents the minimum recommended viability level for probiotics. Different letters denotes significant differences in viable counts between the samples 


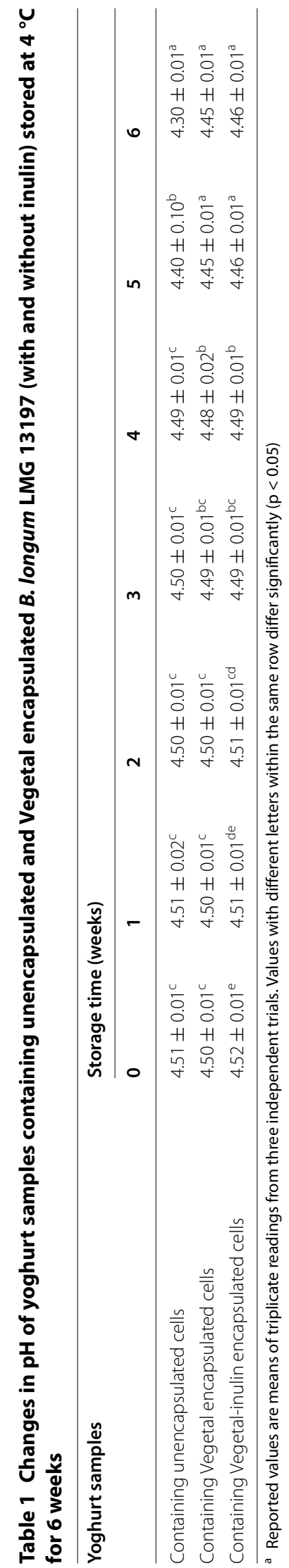


$\mathrm{pH}$ was less than what was observed with unencapsulated cells, partially explaining why viability of the cells was not affected as shown earlier (Fig. 2).

There were significant differences $(\mathrm{p}<0.05)$ in colour attributes $\left(\mathrm{L}^{*}, \mathrm{a}^{*}\right.$ and $\left.\mathrm{b}^{*}\right)$ within each of the yoghurt samples containing unencapsulated and encapsulated cells throughout 6 weeks of storage (Table 2). Significant increases $(p<0.05)$ were observed in $L^{*}$ and $b^{*}$ values throughout storage. The presence of inulin had a significant effect $(p<0.05)$ on the lightness $\left(\mathrm{L}^{*}\right)$ and yellowness $\left(\mathrm{b}^{*}\right)$ of yoghurt. A reduction in $\mathrm{a}^{*}$ values with significant differences $(\mathrm{p}<0.05)$ within the samples was observed throughout 6 weeks of storage.

\section{Discussion}

The decrease of unencapsulated cells during exposure to SGF after $2 \mathrm{~h}$ has also been reported by researchers elsewhere. Hansen et al. (2002), showed a 3-4 $\log$ decrease in $B$. longum Bb46 after $2 \mathrm{~h}$ while De Castro-Cislaghi et al. (2012) reported a 1.51 log decrease in unencapsulated B. lactis $\mathrm{Bb} 12$ at $\mathrm{pH} 2$. In comparison to the unencapsulated cells, encapsulation preserved viability of probiotic cells. The number of cells released from Vegetal matrix in SGF was higher than that of Vegetal-inulin, suggesting that addition of inulin improved the effectiveness of Vegetal to protect bifidobacteria during exposure to SGF. Therefore, encapsulation with Vegetal-inulin performed better at protecting the cells from gastric acidity.

In agreement with previous report by Thantsha et al. (2009), there was a continuous reduction in viable numbers of unencapsulated B. longum $\mathrm{Bb} 46$ cells in SIF. On the other hand, during exposure to SIF, cells encapsulated in Vegetal and Vegetal-inulin matrices were gradually released to numbers recommended for the provision of health benefits. The increase in numbers of viable cells for both encapsulated matrices indicated that in the SIF ( $\mathrm{pH}$ 6.8), the matrices were able to spontaneously disintegrate to release the cells. A gradual release of the viable cells is much more desirable than burst release, as studies have reported that burst release leads to higher cell delivery, which can affect the ability of the matrix to maintain long term controlled release of cells (Huang and Brazel 2001). In support of our findings, Okuro et al. (2013) demonstrated that lipid microcapsules with prebiotics were disintegrated at $\mathrm{pH}$ 6.5, leading to the release of encapsulated bacteria. Although both matrices protected and released the cells in SIF, this study suggested that Vegetal-inulin matrices released higher numbers of viable cells. Therefore, Vegetal-inulin has more potential to efficiently protect the cells in the upper gastrointestinal tract and then release them in sufficient numbers for colonization in the lower gastrointestinal tract.

Since bifidobacteria are sensitive to low pH (Sun and Griffiths 2000), continuous exposure of the unencapsulated cells to the acidic environment of yoghurt would cause a reduction in their numbers. Our results have shown that effective release of bacteria from Vegetal matrix occurs at $\mathrm{pH}$ of 6.8, close to neutral. Therefore, it would be expected that the matrix would not spontaneously release most of the cells into the acidic environment of yoghurt ( $\mathrm{pH} 4.5)$. Hence, the high numbers of viable cells released after dissolution of the matrices at the end of storage period were anticipated.

Our previous research reported encapsulation efficiencies of 88 and $82 \%$ for Vegetal and Vegetal-inulin matrices, respectively (Amakiri et al. 2015). The actual amount of viable cells encapsulated within the Vegetal and Vegetal-inulin matrices were 7.48 and 6.97 


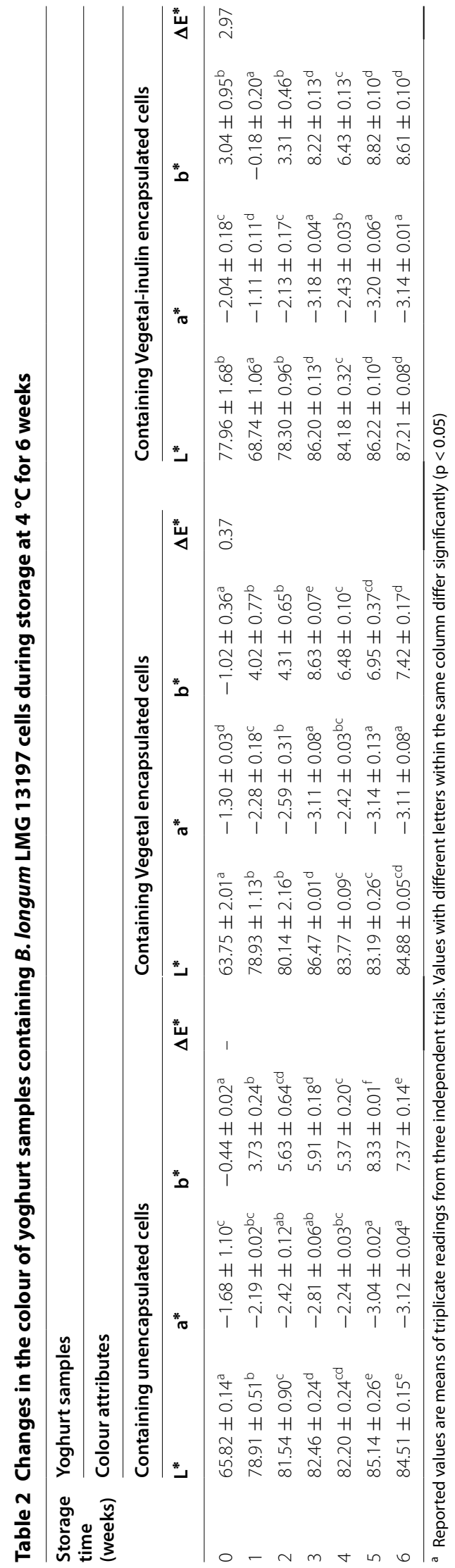


$\log \mathrm{cfu} \mathrm{mL}^{-1}$, respectively. Therefore, viable counts obtained during week 0 represent viability of 85 and $92 \%$ of the bacteria encapsulated within these matrices, respectively. These data thus indicated sufficient protection and release of B. longum cells from both matrices. Worth noting are higher levels of bacterial viability obtained for both matrices after 6 weeks, which corresponds to viability of $>90 \%$ of the encapsulated bacterial cells. Whereas an increase in numbers of viable cells was observed for encapsulated bacteria, a $68 \%$ reduction in viability of the unencapsulated cells was observed. The high numbers of viability for encapsulated bacteria can be attributed to firstly, the ability of the encapsulating matrices to physically retain the bifidobacteria cells within, thereby protect the cells from detrimental factors such as yoghurt acidity and exposure to oxygen. Encapsulation in Vegetal-inulin matrix provided better protection for the cells, possibly because inulin provided extra solids, which have been reported to improve probiotic protection (Capela et al. 2006). The presence of inulin thus afforded the bacteria additional nutrients which enhanced their growth subsequent to their release, thereby providing more suitable growth conditions than was available for bacteria released from Vegetal matrix without inulin. Boeni and Pourahmad (2012) reported that the addition of $2 \%$ inulin improved viability of Lactobacillus casei and L. acidophilus for 3 weeks. Similarly, Akalin et al. (2004) reported higher counts of B. longum in yoghurts containing prebiotics. Secondly, the higher numbers of viable cells at 6 weeks could also be due to enhanced dissolution of the matrices subsequent to suspension of microparticles in a food matrix over a period of time. Although this may initially seem alarming as it suggested potential compromise of the protection efficiency of the matrices over time, considering the normal shelf life of yoghurt, which is generally between 20 and 40 days, and viable counts obtained after such period in this study, the results indicated that the encapsulated cells will be sufficiently protected for the duration of yoghurt's shelf life. Future studies employing sensory analysis with trained panellists are however needed to establish whether prolonged refrigeration of yoghurt containing Vegetal-inulin encapsulated $B$. longum LMG 13197 will not negatively affect the texture and taste of yoghurt.

The continued production of acids by bifidobacteria cells possibly contributed to the drop in pH of yoghurt containing unencapsulated cells (Samona et al. 1996). It has been reported that bifidobacteria produce acetic and lactic acids at proportions of 3:2, which when in excess can lead to undesirable effects in yoghurt (Arai et al. 1996). Conversely, Vegetal and Vegetal-inulin matrices minimized alterations to $\mathrm{pH}$ of yoghurt by retaining the cells and possibly the metabolites produced by the cells. Thus, the quality of yoghurt was less likely to be negatively affected. Kailasapathy (2006) reported that post acidification was slower in yoghurt samples containing encapsulated probiotics as opposed to those containing free probiotics after 6 weeks of storage at $4{ }^{\circ} \mathrm{C}$. Other studies have reported slight decrease in $\mathrm{pH}$ values of yoghurt containing prebiotics over storage time (Akalin et al. 2004; Boeni and Pourahmad 2012).

Colour is a unique characteristic in yoghurt, which if negatively affected, can lead to rejection of yoghurt by the consumers, leading to increased economic losses (Arai et al. 1996). Hence, it is important that the colour of yoghurt after fortification with encapsulated probiotics is monitored to ensure that it remains of the quality acceptable to consumers. The increase in $\mathrm{L}^{*}$ and $\mathrm{b}^{*}$ values of the samples indicated the tendency towards white and yellow colours (Aryana and McGrew 2007). This might be attributed to the 
colour of the ingredients present in the yoghurt samples, which include the whitish colour of inulin and the white to cream colour of milk. The affinity to a more yellowishwhite (cream) colour was seen with the addition of inulin as reported by Damian (2013), who found a high $\mathrm{L}^{*}$ value for yoghurt samples containing inulin. The reduction in $\mathrm{a}^{*}$ values might be attributed to the presence of riboflavin, a green compound which has been regarded as part of milk's natural pigment concentration, and thus contributes to the colour of milk (Nozière et al. 2006). Although all the yoghurts appeared cream in colour at the end of storage, the total colour difference observed between the unencapsulated and encapsulated samples suggests that addition of Vegetal and Vegetal-inulin encapsulated B. longum to yoghurt were minor to not obvious to the human eye and will have no negative effect on its acceptability by consumers (Martínez-Cervera et al. 2011).

\section{Conclusions}

Freeze dried Vegetal BM 297 ATO microparticles offered protection to B. longum LMG13197 cells during exposure to simulated gastrointestinal fluids and in yoghurt. The microparticles protected bacteria from gastric acidity and subsequently released sufficient amounts of viable cells into the simulated intestinal fluid, an indication of release of sufficient cells for colonization of the colon. Post acidification of yoghurt was minimized in the presence of encapsulated B. longum and its total colour change was considered minor or not noticeable to the human eye. In all cases, Vegetal-inulin microparticles were more protective to B. longum than Vegetal alone. Therefore, Vegetal-inulin microparticles were suitable for incorporation of probiotic cultures into fermented dairy products such as yoghurt.

\section{Authors' contributions}

ACA: Data acquisition and analysis; drafted the manuscript. MST: Conception and design of the study, data analysis and helped draft the manuscript. Both authors read and approved the final manuscript.

\section{Author details}

${ }^{1}$ Department of Microbiology and Plant Pathology, University of Pretoria, Lynwood Road, Pretoria 0002, South Africa.

2 Department of Microbiology and Plant Pathology, Faculty of Natural and Agricultural Sciences, University of Pretoria, New Agricultural Sciences Building, Lunnon Road, Pretoria 0002, South Africa.

\section{Acknowledgements}

This study was funded by the National Research Foundation (NRF) of South Africa.

Competing interests

Both authors declare that they have no competing interests.

Received: 30 March 2016 Accepted: 5 August 2016

Published online: 12 August 2016

\section{References}

Akalin AS, Fenderya S, Akbulut N (2004) Viability and activity of bifidobacteria in yoghurt containing fructooligosaccharides during refrigerated storage. Int J Food Sci Technol 39(6):613-621

Allgeyer LC, Miller MJ, Lee SY (2010) Sensory and microbiological quality of yoghurt drinks with prebiotics and probiotics. J Dairy Sci 93:4471-4479

Amakiri AC, Kalombo L, Thantsha MS (2015) Production and characterization of freeze dried Vegetal BM 297 ATO-inulin lipid-based synbiotic microparticles containing Bifidobacterium longum LMG 13197. J Microencapsul 32(8):820-827

Arai O, Sakaki M, Sugimoto T (1996) Effectiveness of yoghurt incorporated with enteric bifidobacteria. Food Ind 39(1):53-56

Aryana KJ, McGrew P (2007) Quality attributes of yoghurt with Lactobacillus casei and various prebiotics. Food Sci Techno 40:1808-1814

Boeni S, Pourahmad R (2012) Use of inulin and probiotic lactobacilli in synbiotic yoghurt production. Ann Biol Res 3(7):3486-3491 
Burgain J, Gaiani C, Linder M, Scher J (2011) Encapsulation of probiotic living cells: from the laboratory scale to industrial applications. J Food Eng 104:467-483

Capela P, Hay TKC, Shah NP (2006) Effect of cryoprotectants, prebiotics and microencapsulation on the survival of probiotic organisms in yoghurt and freeze dried yoghurt. Food Res Int 39:203-211

Damian C (2013) Influence of dietary fiber addition on some properties of yoghurt. Ovidius Univ Ann Chem 24(1):17-20

De Castro-Cislaghi FP, Carina Dos Reis ES, Fritzen-Freire CB, Lorenz JG, Sant'Anna AS (2012) Bifidobacterium Bb-12 microencapsulation by spray drying with whey: survival under simulated gastrointestinal conditions, tolerance to $\mathrm{NaCL}$, and viability during storage. J Food Eng 113:186-193

Doleyres Y, Lacroix C (2005) Technologies with free and immobilised cells for probiotic bifidobacteria production and protection. Int Dairy J 15:973-988

FAO/WHO (2002) Guidelines for the evaluation of probiotics in food. Joint FAO/WHO Working Group report on drafting guidelines for the evaluation of probiotics in food. ftp://ftp.fao.org/es/esn/food/wgreport2.pdf. Accessed 18 Feb 2013

Fritzen-Freire CB, Prudencio ES, Amboni RDMC, Pinto SS, Negrão-Murakami AN, Murakami FS (2012) Microencapsulation of bifidobacteria by spray drying in the presence of prebiotics. Food Res Int 45:306-312

Gattefossé SAS, technical and material safety data sheet (2010) Regulatory Department, regulatory@gattefosse.com. Accessed 20 Apr 2013

Hansen LT, Allan-Wojtas PM, Jin YL, Paulson AT (2002) Survival of calcium-alginate microencapsulated Bifidobacterium spp in milk and in simulated gastrointestinal conditions. Food Microbiol 19:35-45

Huang X, Brazel CS (2001) On the importance and mechanisms of burst release in matrix-controlled drug delivery systems. J Control Release 73:121-136

Kailasapathy K (2006) Survival of free and encapsulated probiotic bacteria and their effect on the sensory properties of yoghurt. Food Sci Technol 39(10):1221-1227

Kalliomäki M (2009) Probiotics, prebiotics and synbiotics; a hope or hype in allergy? Clin Exp Allergy 40:694-696

Kelly G (2009) Inulin-type prebiotics: a review (part 2). Altern Med Rev 14(1):36-55

Lian WC, Hsiao HC, Chou CC (2003) Viability of microencapsulated bacteria in simulated gastric juice and bile solution. Int J Food Microbiol 86:293-301

Martínez-Cervera S, Salvador A, Muguerza B, Moulay L, Fiszman SM (2011) Cocoa fibre and its application as a fat replacer in chocolate muffins. Food Sci Technol 44:729-736

Nozière P, Graulet B, Lucas A, Martin B, Groiler P, Doreau M (2006) Carotenoids for ruminants: from forages to dairy products. Anim Feed Sci Technol 131:418-450

Okuro PK, Thomazini M, Balieiro JCC, Liberal RDCO, Fávaro-Trindade CS (2013) Co-encapsulation of Lactobacillus acidophilus with inulin or polydextrose in solid lipid microparticles provides protection and improves stability. Food Res Int 53:96-103

Pimentel TC, Cruz AG, Prudencio SH (2013) Short communication: influence of long chain inulin and Lactobacillus paracasei subspecies paracasei on the sensory profile and acceptance of a traditional yogurt. J Dairy Sci 96:6233-6241

Roberfroid MB (2007) Concepts and strategy of functional food science: the European perspective. Am J Clin Nutr 71:1660-1664

Samona A, Robinson RK, Marakis S (1996) Acid production by bifidobacteria and yoghurt bacteria during fermentation and storage of milk. Food Microbiol 13:275-280

Shah NP (2000) Probiotic Bacteria: selective enumeration and survival in dairy foods. J Dairy Sci 83:894-907

Sultana K, Godward G, Reynolds N, Arumugaswamy R, Peiris P, Kailasapathy K (2000) Encapsulation of probiotic bacteria with alginate-starch and evaluation of survival in simulated gastrointestinal conditions and in yoghurt. Int J Food Microbiol 62:47-55

Sun W, Griffiths MW (2000) Survival of bifidobacteria in yoghurt and simulated gastric juice following immobilisation in gellan-xanthan beads. Int J Food Microbiol 61:17-25

Thantsha MS, Cloete TE, Moolman FS, Labuschagne WP (2009) Supercritical carbon dioxide interpolymer complexes improve survival of B. longum Bb-46 in simulated gastrointestinal fluids. Int J Food Microbiol 129:88-92

United States Pharmacopeial Convention (2005) United States Pharmacopeia, 25th edn. Webcom, Toronto

\section{Submit your manuscript to a SpringerOpen ${ }^{\circ}$ journal and benefit from:}

- Convenient online submission

- Rigorous peer review

- Immediate publication on acceptance

- Open access: articles freely available online

- High visibility within the field

- Retaining the copyright to your article

Submit your next manuscript at $\boldsymbol{\nabla}$ springeropen.com 